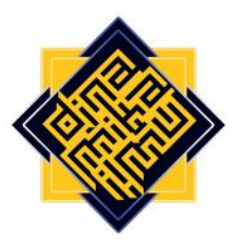

\title{
Academic Procrastination of High School Students During the Covid-19 Pandemic: Review from Self-Regulated Learning and the Intensity of Social Media
}

\author{
Eva Latipah \\ Universitas Islam Negeri Sunan Kalijaga, Yogyakarta, Indonesia \\ eva.latipah@uin-suka.ac.id \\ Hanif Cahyo Adi Kistoro \\ Universitas Ahmad Dahlan Yogyakarta, Indonesia \\ hanif.kistoro@pai.vad.ac.id \\ Farah Dina Insani \\ Universitas Islam Negeri Sunan Kalijaga, Yogyakarta, Indonesia \\ 19204010033@student.vin-suka.ac.id
}

\section{Abstract}

The Covid-19 pandemic has an impact on increasing procrastination of study assignments (academic procrastination) in Islamic Religious Education in Senior High Schools. This occurs because students have low self-regulated learning (SRL), and on the other hand, have high social media intensity. This study aims to examine the relationship between SRL and the intensity of social media with academic procrastination. This research is quantitative using the SRL scale, academic procrastination scale, and social media intensity questionnaire for data collection. The sample was determined using the Slovin formula in order to obtain a sample of 118 students. The data analysis technique used regression analysis. The results showed: 1 ) There was a significant negative relationship between selfregulated learning and academic procrastination with a value of $r=-4.125$ and $a$ value of $p=0.00(p<0.05) .2)$ There is a significant positive relationship between the intensity of social media and academic procrastination with $r=5.111$ and $p=0.00$ $(p<0.05) .3)$ There is a significant positive relationship between self-regulated learning and the intensity of social media simultaneously with academic 
Eva Latipah et al.

procrastination with a value of $F=15.106$ and a value of $p=0.00(p<0.05)$. 4) The effective contribution (R2) of the two variables is $30.5 \%$. Thus, self-regulated learning and the intensity of social media can be predictors of PAl's academic procrastination.

Keywords: Academic Procrastination, Self-Regulated Learning, Social Media Intensity

\section{A. Introduction}

The Covid-19 pandemic has been going on for more than a year in Indonesia. This has an impact on various aspects of life including the education sector. All levels of education apply online learning, namely online learning using certain media (Radino et al., 2021) such as google classroom, WhatsApp, e-learning, email, and so on. In online learning, students and teachers do not meet face-to-face but only meet virtually. This has an impact on the lack of control from teachers to students. Teachers cannot directly control the activities of their students so that students feel free to do anything because they feel that no one is watching or reminding them. Further impact, students are often even having fun surfing in cyberspace when learning online. Instead, they feel bored, lonely, and sleepy (PreLiminary Results, 2020). In such conditions, students feel lazy to focus on lessons, especially to do their assignments. This also occurs in the work of Islamic Religious Education (PAI) subjects as subjects that are delivered in lectures through online media. If the feeling of laziness to learn overwhelms them, and on the other hand, students feel happy surfing in cyberspace, then what can happen is students procrastinating all forms of schoolwork, including delaying PAl subject assignments. Procrastinating study assignments are known as academic procrastination.

Academic procrastination can occur in all circles, both by students in schools, students in universities, even by employees in the world of work. Senior High School (SMA) students are individuals aged 12-18. Psychologists refer to this age as adolescence. According to Piaget, adolescent cognitive development has reached the stage of formal action or formal operations. Teens are mentally able to think logically about various abstract ideas. In other words, formal operational thinking is more hypothetical-abstract than systemic-scientific problem solving rather than concrete (Nugteren et al., 2018). Teenagers at that age often experience various kinds of problems. Usually, the problems that are often experienced by adolescents are such as a crisis of trust, friendship, romance, and also learning problems. Common learning problems experienced by students are delays in completing assignments given by teachers for various reasons such as laziness, time management, doubts in carrying out assignments, perfectionists, and so on. Delays in doing school work like this are often referred to as academic procrastination.

Procrastination in the academic world is called academic procrastination (Munawaroh et al., 2017). Academic procrastination is usually in the form of delays in assignments, studies, delays in entering classes that students or students have carried out. Procrastination, other than delaying time to start a task or work, can be considered a form 
of task avoidance because of feelings of displeasure with the subject or job given for fear of failure (Ilyas \& Suryadi, 2017). Besides, procrastination is also an individual habit in responding to something, especially in the academic field (Saman, 2017).

Previous research findings show that procrastination can occur in various fields such as education, work, social, and others (Fauziah, 2016). Besides that, procrastination can also be caused by many factors, such as self-regulation (Latipah, 2010; Ulum, 2016), low learning motivation (Latipah et al., 2021; Nitami et al., 2015), control, and time management (Ika Sandra \& Djalali, 2013) self-confidence (Ramadhan \& Winata, 2016), depression or stress (Anggawijaya, 2013), low self-efficacy (Damri et al., 2017), self-control (Aini \& Mahardayani, 2017), low competitiveness (Jannah \& Muis, 2014), fear of failure and the influence and intensity of using social media (Yang et al., 2018).

Procrastination experienced by students, if not identified and addressed, will hurt students' academic activities such as low learning achievement and final exam results. This study will examine academic procrastination for high school students in terms of selfregulation and the intensity of social media, especially during a pandemic.

\section{B. Literature Review}

According to Knaus, procrastination is an automatic problem habit of putting off an important and timely activity until another time. It's a process that has probable consequences' (Knaus, 2010). Procrastination is a matter of automatically putting off important activities and being on time until another time. It is a process that has both possibilities and consequences. Academic procrastination that is carried out leads to fun things such as hanging out with friends, watching hours of movies, playing online games, social media, and so on. This activity is more fun than academic assignments so that the collection of school assignments is delayed (Ni'matuzahroh, 2019).

The form of procrastination as proposed by Ferrari, includes functional procrastination and dysfunctional procrastination. Functional procrastination is delaying a task or job in order to obtain more accurate information. Dysfunctional procrastination is delaying tasks or work without a purpose; this is bad and causes problems. The second type is called decisional procrastination and avoidance and behavioral procrastination. Decisional procrastination, which is a delay in making decisions, is a coping to avoid the possibility of stress and adjust to making decisions that are perceived as stressful. It is associated with forgetfulness, a failure of cognitive processing but is not associated with a lack of intelligence. Avoidance and behavioral procrastination are delays invisible behavior, this is done to avoid tasks that are felt to be unpleasant and difficult to do (Ferrari \& Tice, 2000).

Academic procrastination specifically includes behaviour that involves an element of procrastination both when starting and completing a task; produce further consequences such as delays in completing tasks or failure to complete tasks; include tasks that are perceived as essential tasks to be done, such as school assignments; produce unpleasant emotional states such as feelings of anxiety, panic, guilt, anger, and so on (Kroese et al., 2014). This will affect the learning process of students and even the results of learning 


\section{Eva Latipah et al.}

achievements that have been carried out because students cannot follow the learning process properly.

Academic procrastination can be seen based on five aspects, namely: 1) delays in working on and completing assignments; 2) Doing fun activities, such as watching TV, traveling, playing games, and social media; 3) Time gap between plans and actual performance and time management, procrastinators often have difficulty doing something within a predetermined time limit; 4) Lack of motivation to learn, procrastinators show low academic motivation; 5) Fear of failure and work discipline (Kim $\&$ Seo, 2015). The high school students in this study did almost all of these activities, and the most frequently done were procrastinating from school, playing games, and surfing the internet.

Academic procrastination usually does not just happen, but there are factors behind it. Among the influencing factors is 1) irrational thoughts, namely the assumption that a task must be completed perfectly; 2) Anxiety because of their ability to be evaluated, fear of failure and difficulty making decisions, or because they need help from others to do their work; 3) Lazy and has difficulty managing time and dislikes tasks; 4) The existence of rewards and punishments so that they feel safer if they do not do it immediately because it can produce something that is not optimal; 5) Observation factors from the environment such as school or family; 6 ) The piling up of tasks that must be done immediately so that the acceleration of one task causes the delay of another task (Wolters \& Benzon, 2013). These factors are the cause of the emergence of academic procrastination for students.

The procrastination experienced by students during this pandemic shows that they have low self-regulated learning (SRL). This can be seen from the low intrinsic motivation shown in the behavior of weak self-control. The students feel that the absence of direct observation from the teacher makes them free, not having to focus on the ongoing subject. They are also very weak in using strategies that are in accordance with the material they have to learn, such as memorization material in PAI is actually quite learned using mnemonic strategies or rather complex PAI materials that should be learned using a concept map strategy (Latipah et al., 2020). In this case, they have neglected to choose the appropriate strategies due to the absence of observation and because they are too cool to be fluent in cyberspace (social media). Even when they are bored and bored with the material presented by the teacher, they do not know what to do. They don't try to find a solution to the boredom and boredom they experience in order to keep learning, instead they compensate for their boredom and boredom by surfing in cyberspace. As a result, they did not study and their schoolwork was postponed so that the tasks piled up.

Self-regulated learning is the process of activating and maintaining thoughts, behavior, and emotions to achieve learning goals (Zimmerman, 2013). In line with this Latipah (Latipah et al., 2021) defines self-regulated learning as the application of metacognitive and self-regulation, where metacognitive is the control and control of thought processes, while self-regulation is the control and control of emotions for learning. Self-regulated learner transforms mental abilities into academic skills and strategies (Virtanen et al., 2015). Self-regulated learners combine academic skills and self-control 
that make learning easy and thus more motivated. In short, self-regulated learners have the skills (skills) and will (will) to learn (Brandmayr, 2020; Kesuma et al., 2020).

The description above explains that self-regulated learning is influenced by three factors, namely: knowledge, motivation, and self-discipline (Bernacki et al., 2015). A selfregulated learner needs knowledge about himself (his talents and interests, learning styles, strengths, and weaknesses), the material he studies (the more material he learns which has an impact on the more knowledge he has, the easier it is to learn many things), tasks (different tasks require different approaches or strategies, for example, simple rote tasks using mnemonic strategies and complex rote tasks using concept map strategies, etc.), strategies for learning (skimming strategies, careful reading strategies, memorization strategies, and strategies organizing material). In other words, they know themselves and how they can best learn.

Self-regulated learners find schoolwork very interesting for them because they value learning. Even if they do not have the enthusiasm to learn (not intrinsically motivated), they are trying seriously and earnestly looking for the desired benefits from their schoolwork. Not only having motivation, self-regulated learners perform self-discipline or more precisely volition/will power, namely protecting opportunities to achieve goals. When distractions come their way, self-regulated learners know exactly how to deal with them. For example, when he is lazy to approach her, he will go to the beach for a moment or listen to music, or just drink coffee at a café.

According to Eveline (Crone \& Konijn, 2018), the nerves in adolescence have shown the development of the prefrontal cortex, an important area for emotion regulation, maturing into early adulthood. A better understanding of the interactions between brain regions that show direct responses to emotional content, and brain regions that help regulate these responses may explain how adolescents regulate their behavior in relation to media-based interactions. When a teenager is addicted to social media, it can affect the pre-frontal cortex (PFC). PFC is the part of the brain that controls emotions, self-control, responsibility, decision-making, and other moral values. Teens who are addicted to social media have excess levels of the hormone dopamine in their brains, which causes PFC to be disrupted and malfunction. Dopamine is a hormone in the brain that never stops working. Its job is to send nerve signals to the brain. Without this hormone, the brain cannot function at all (Kurniasanti et al., 2019).

\section{Research Methodology}

From the above phenomenon, researchers are interested in researching academic procrastination considering that many students do procrastination which in the end has an impact on their academic achievement. This research is a type of quantitative research because the symptoms from the observations are analyzed quantitatively based on statistical data obtained through a questionnaire instrument using a scale that has been made. 
Eva Latipah et al.

The population of this study were all 288 students of class II Muhammadiyah 1 Temanggung-Central Java High School (SMA) Muhammadiyah. Determination of the sample using purposive random sampling technique, namely by determining 3 classes of Natural Sciences (IPA) and 3 classes of Social Sciences (IPS), then spreading the scale to 6 randomly selected classes, and obtained 168 students with details as shown in Table 1. Sampling using the Slovin formula from a total population of 168 obtained a total sample of 118 students. The data collection technique was carried out by distributing google forms which were distributed to students and students with the help of the homeroom teacher in each class.

\begin{tabular}{lcc}
\multicolumn{3}{c}{ Table: 1 Description of Research Subjects $(\mathrm{N}=\mathbf{1 6 8})$} \\
\hline Class & Amount & Percentage \\
\hline Science Class 1 & 26 & 15 \\
Science Class 2 & 26 & 16 \\
Science Class 3 & 26 & 16 \\
Social Class 1 & 30 & 18 \\
Social Class 2 & 30 & 18 \\
Social Class 3 & 30 & 18 \\
\hline Total & $\mathbf{1 6 8}$ & $\mathbf{1 0 0 \%}$ \\
\hline
\end{tabular}

The scale distribution was carried out in early January 2020, precisely on 12-26 January 2020, after obtaining prior permission from the school. Scaling is done by using Google Forms. As a strategy to increase the spirit of research subjects in filling out the scale, a reward is provided in the form of giving 50 thousand credits for the first 20 people who fill in. On the 27 th the entire scale was collected and ready to be processed.

The instrument used is a procrastination scale which is compiled with reference to Ferrari's procrastination theory which involves four aspects, namely procrastination, time lag, more enjoyable activities, and lack of motivation. Likewise with self-regulated learning using a self-regulated learning scale that was compiled by referring to Zimmerman's theory which includes three aspects, namely metacognition, learning motivation, and behavior in learning. Furthermore, for the intensity of social media using a self-made questionnaire with reference to two aspects, namely frequency, and duration.

Based on the number of variables in this study, there are three instruments used, namely the academic procrastination scale, the self-regulated learning scale, and the social media intensity scale. The academic procrastination scale was developed based on a theory that has been built which has four aspects, namely procrastination, time gaps, more enjoyable activities, and less motivation. These four aspects are described in 15 favorite statement items and 15 unfavorable items. The self-regulated learning scale was developed based on the theory that has been built by involving three aspects, namely metacognition, learning motivation, and learning behavior. These three aspects are described in 13 items of favorable statements and 13 items of unfavorable statements. The intensity scale of social media uses a theory that has been built by involving two aspects, namely the frequency and duration of social media which are described in 8 favorite statement items and 8 unfavorable statement items. The answer options of the three 
scales are arranged using a Likert scale with answer scores of 1, 2, 3, 4, and 5 for the unfavorable statement item, and $5,4,3,2$, and 1 for the favorite statement item with alternative answers almost always, very often, sometimes, very rarely, and almost never (Rea \& Parker, 2014). The data analysis technique used multiple correlation analysis using SPSS 24 software for windows.

\section{Findings}

\section{Test the Validity and Reliability of Research Instruments}

The results of the validity test for the academic procrastination scale showed that from 30 items there were 18 valid items and 12 invalid items. Valid items have item correlations with a total score that ranges between -0.129-0.911 with a reliability level of 0.952 . The results of the validity test for the self-regulated learning scale show that of the 26 items, there are 24 valid items and 2 invalid items. Valid items have item correlations with a total score that ranges between $0.12-0.8$ with a reliability level of 0.903 . Furthermore, the results of the validity test of the intensity of the social media questionnaire showed that of the 16 items there were 16 valid items. Valid items have item correlations with a total score that ranges between $0.36-0.747$ with a reliability level of 0.902 . Thus, the two scales of this study are declared valid and reliable.

\section{Test for Normality, Linearity, and Multicollinearity of Research Data}

The prerequisite test results on the research data showed normal research data with a value of 0.176 and $p=0.000$. Based on the linearity test, it shows that the research data is linear with a value of $\mathrm{F}=1.444$ and $\mathrm{p}=1.4$ while for the intensity of social media and academic procrastination with a value of $F=0.997$ and $p=492$. Based on the multicollinearity test, it is known that the tolerance value is 0.801 , which means the tolerance value is $0.801>0.01$ and the VIF value is 1.249 , which means the VIF value is $1.248<10.00$, so it can be concluded that there is no multicollinearity between the two independent variables in this study.

\section{Descriptive Analysis}

The description of the research data as a whole is shown in Table 2.

Table: 2 Description of Research Data $(\mathrm{N}=72)$

\begin{tabular}{ccccc}
\hline \multirow{2}{*}{ Variable } & \multicolumn{5}{c}{ Empiricaal } \\
\cline { 2 - 5 } & Min & Max & Mean & SD \\
\hline Academic Procrastination & 20 & 64 & 36,26 & 10,684 \\
\hline Self Regulated Learning & 13 & 82 & 56,74 & 12,241 \\
\hline Social Media Intensity & 9 & 64 & 39,72 & 8,732 \\
\hline
\end{tabular}

The description of the data above is strengthened by the following categorization to determine the position of the subject in the study. The categorization results are as shown in Table 3. 
Eva Latipah et al.

Table: 3 Subject Categories Based on Academic Procrastination Variables

\begin{tabular}{c|c|c|c}
\hline Score & Criteria & Frequency & Percentage \\
\hline$<20$ & Very low & 2 & $2,8 \%$ \\
\hline $21-31$ & Low & 19 & $26,4 \%$ \\
\hline $32-42$ & Average & 20 & $27,8 \%$ \\
\hline $43-53$ & High & 26 & $36,1 \%$ \\
\hline$>54 \quad$ Very High & 5 & $6,9 \%$ \\
\hline \multicolumn{2}{|c|}{ Total } & 72 & $100 \%$ \\
\hline
\end{tabular}

Table: 1 An example of a table

\begin{tabular}{lcc}
\hline An example of a heading & Column A (t) & Column B (T) \\
\hline Add an entry & 1 & 2 \\
Add an entry & 1 & 2 \\
Add an entry & 1 & 3 \\
\hline
\end{tabular}

Based on the results of the descriptive analysis of academic procrastination variables, it is known that the academic procrastination of class XI students is at very low criteria as many as 2 students with a percentage of $2.8 \%$, on the low criteria as many as 19 students with a percentage of $26.1 \%$, on the moderate criteria as many as 20 students with a percentage $27.2 \%$, on the high criteria were 26 students with a percentage of $36.1 \%$ and the last on the very high criteria were 5 students with a percentage of $6.9 \%$. It can be concluded that class XI students of SMA Muhammadiyah 1 Temanggung have high academic procrastination with a percentage of $36.1 \%$.

Table: 4 Subject categories based on self-regulated learning variables

\begin{tabular}{c|c|c|c}
\hline Score & Criteria & Frequency & Percentage \\
\hline$>38$ & Very Low & 4 & $5,6 \%$ \\
\hline $39-51$ & Low & 24 & $33,3 \%$ \\
\hline $52-63$ & Avarage & 22 & $30,6 \%$ \\
\hline $64-75$ & High & 20 & $27,8 \%$ \\
\hline$>76$ & Very High & 2 & $2,8 \%$ \\
\hline \multicolumn{2}{|c|}{ Total } & 72 & $100 \%$ \\
\hline
\end{tabular}

Based on the results of the descriptive analysis of self-regulated learning variables, it is known that the self-regulated learning of class XI students is at very low criteria as many as 4 students with a percentage of $5.6 \%$, on the low criteria as many as 24 students with a percentage of $33.3 \%$, on the moderate criteria as many as 22 students. with a percentage of $30.6 \%$, on the high criteria, as many as 24 students with a percentage of $27.8 \%$, and the last on the very high criteria were 2 students with a percentage of $2.8 \%$. So it can be 
concluded that class XI students of SMA Muhammadiyah 1 Temanggung have low selfregulated learning with a percentage of $33.3 \%$.

Table: 5 Subject category based on Social Media Intensity variable

\begin{tabular}{c|c|c|c}
\hline Score & Criteria & Frequency & Percentage \\
\hline$>27$ & Very Low & 1 & $1,4 \%$ \\
\hline $28-35$ & Low & 23 & $31,9 \%$ \\
\hline $36-44$ & Avarage & 34 & $47,2 \%$ \\
\hline $45-53$ & High & 6 & $8,3 \%$ \\
\hline$>54$ & Very High & 8 & $11,1 \%$ \\
\hline \multicolumn{2}{|r|}{ Total } & 72 & $100 \%$ \\
\hline
\end{tabular}

Based on the results of the descriptive analysis of the social media intensity variable, it is known that the social media intensity of class XI students is at very low criteria as many as 1 student with a percentage of $1.4 \%$, on the low criteria as many as 23 students with a percentage of $31.9 \%$, on the medium criteria as many as 34 students with a percentage of $47.2 \%$, on the high criteria as many as 6 students with a percentage of $8.3 \%$ and the last on the very high criteria as many as 8 students with a percentage of $11.1 \%$. So it can be concluded that class XI students of SMA Muhammadiyah 1 Temanggung have moderate social media intensity with a percentage of $47.2 \%$.

\section{Hypothesis Test}

Hypothesis testing in this study uses regression analysis. The following are the results of the hypothesis testing of self-regulated learning variables and the intensity of social media on academic procrastination.

a. The Correlation Between Self-Regulated Learning and Academic Procrastination

Based on the results of calculations with the help of SPSS software, it shows that the results of the relationship between self-regulated learning and academic procrastination are 4.125 . Then $r$-count was consulted with r-table by first looking for the amount of $d f$ with the provisions $\mathrm{df}=\mathrm{nk}-1$ then $72-2-1=6 \mathrm{~g}$. We found the r-table value with $\mathrm{df}$ of $6 \mathrm{~g}$, namely 0.1968 at the $5 \%$ significance level and 0.2756 at the significance level. $1 \%$. The result of $r$-count is -4.125 so that $r$-count $>r$-table is $-4.125>0.1968$ at the $5 \%$ significance level and $r$-count $>$ r-table is $-4.125>0.2756$ at the $1 \%$ significance level. Thus, there is a significant negative relationship between self-regulated learning and academic procrastination.

b. Correlation Between Social Media Intensity and Academic Procrastination

Based on the results of calculations with the help of SPSS software, it shows that the results of the $r$-count of social media intensity and academic procrastination are 5.112. Then $r$-count is consulted with $r$-table by first finding the magnitude of $\mathrm{df}$ with the provisions of $d f=n k-1$ then $72-2-1=69$. The value of the r-table with $d f$ of 69 is 0.1968 at 


\section{Eva Latipah et al.}

the $5 \%$ significance level and 0.2756 at the significance level $1 \%$. The result of $r$-count is 5.112 so that $r$-count $>$ r-table is $5.112>0.1968$ at a significance level of $5 \%$ and $r$-count $>r$ table is $5.112>0.2756$ at a significance level of $1 \%$. Thus, there is a significant positive relationship between the intensity of social media and academic procrastination.

c. The correlation between Self Regulated Learning and Social Media Intensity Simultaneously with Academic Procrastination

The results of the multiple correlation test of self-regulated learning and the intensity of social media simultaneously with academic procrastination are as follows: the correlation coefficient is $\mathbf{0 . 5 5 2}$. Meanwhile, the simultaneous contribution or contribution of the variable self-regulated learning and the intensity of social media simultaneously on academic procrastination is $30.5 \%$, while $69.5 \%$ is influenced by other variables outside of this study.

d. Contribution of Self-Regulated Learning and Social Media Interactivity to Academic Procrastination

To determine the contribution of the variable self-regulated learning and the intensity of social media to academic procrastination in the multiple correlation test, see the value of $R$, the closer to 1 , the stronger the relationship. The correlation coefficient (R) from the analysis above shows an $R$ of 0.552 so that there is a relationship between selfregulated learning and the intensity of social media with academic procrastination. While the coefficient of determination $\left(R_{2}\right)$ is 0.305 which states the magnitude of the influence of self-regulated learning indicators and the intensity of social media. This means that $30.5 \%$ of students' academic procrastination at SMA Muhammadiyah 1 Temanggung is influenced by self-regulated learning and the intensity of social media, then the remaining $69.5 \%$ is influenced by other factors outside of this study.

\section{E. Discussion}

One of the goals of education is to systematically develop children's abilities in the form of learning in formal and informal schools (Latipah et al., 2020). However, if students do not have the will, self-regulation in learning, and often procrastinate, it will be challenging to develop children's abilities systematically. This is because students do not have the choice to develop their abilities. This is also in line with Ramadhan, which states that procrastination has a relationship with one's motivation, especially in the academic field(Ramadhan \& Winata, 2016).

The multiple correlation test results show that the correlation coefficient is marked 4.125 (-). This indicates that the relationship between the two variables (correlation goes both ways). The higher the self-regulated learning a person has, the lower his academic procrastination will be and vice versa. Then, determine the significance level between the two variables with a two-sided test with a significance level of $5 \%$. The criteria are based on the significance value. $\mathrm{Ha}$ is accepted if the significance value is $<0.05$, and $\mathrm{Ha}$ is rejected if the significance value is $>0.05$. Based on the analysis of multiple correlation tests, it is known that the significance value is 0.000 . Because of the significance value 
$(0.000<0.05), \mathrm{Ha}$ is accepted, meaning that there is a significant negative relationship between independent learning and academic procrastination. This means that good selfmanagement in student learning does not have anything to do with student academic procrastination. This is supported by Motie's research which states that good selfregulation of students will reduce students' academic procrastination (Motie et al., 2012)

The research results above can be understood that people who postpone their academic assignments lack regulation in three aspects: metacognition, learning motivation, and learning behaviour. This study reinforces this view that the results show that procrastinators lack self-regulation in the three areas of regulation, cognition, inspiration, and behaviour proposed in the self-regulation movement. Low self-efficacy for self-regulation is the strongest predictor of procrastination tendencies (Park \& Sperling, 2012).

Students who often procrastinate doing academic assignments prove that the lack of self-regulation skills in learning causes them to be lazy to do their academic studies. Some procrastinators explain that they usually plan to get to work first but get their job done at the last minute. They seem easily distracted by other, more exciting activities and cannot keep themselves motivated to work as they planned. Research from Ulum also states that self-regulated learning will reduce students' academic procrastination (Ulum, 2016).

Self-regulated learning is something that gives the individual strength as an initial approach to the task at hand. People who find homework beneficial will increase motivation to study and activate more learning strategies. This interest or motivation is the starting point for carrying out all activities, especially learning (Brandmayr, 2020). Nitami's research also states that high motivation in learning will provide enthusiasm and good learning strategies and reduce academic procrastination (Nitami et al., 2015).

In addition, independence in learning is very influential on student achievement. Independence is students' confidence in their ability to achieve learning goals. Independence in education helps students to prepare for difficulties, work harder, and reduce negative emotional responses. Independence can change people's attitudes, thoughts, and behaviour. Independence contributes to the strengths and weaknesses of student motivation. Based on several studies, it can be concluded that self-efficacy can foster learning motivation when the enthusiasm for learning is raised, and students can control their knowledge and improve learning outcomes.

Based on the findings obtained from this study, several self-regulatory strategies are significant predictors of academic procrastination. That is, students who have an internal assessment of goals rarely procrastinate. This is in line with the results of previous studies. As stated by Zimmerman that learning to self-regulate will rarely procrastinate because it has strategic considerations and planning. Another opinion expressed by Wolters shows that those who have a mastery approach goal will not delay their task. Those who have this goal are interested in learning for that purpose (Motie et al., 2012). Academic procrastination is a behaviour that students must avoid because it has a negative impact, especially on academic achievement. 


\section{Eva Latipah et al.}

The multiple correlation test results show that the correlation coefficient is 5.112 with a sign (+); this indicates that the relationship between the two variables (correlation runs in the same direction). The rise will follow an increase in the intensity of social media in academic procrastination. A decline will follow a decrease in the power of social media in academic procrastination. Then, determine the significance level between the two variables with a two-sided test with a significance level of $5 \%$. The test criteria are based on the significance value. $\mathrm{Ha}$ is accepted if the significance value is $<0.05$, and $\mathrm{Ha}$ is rejected if the significance value is $>0.05$. Based on the multiple correlation test analysis results, it is known that the significance value is 0.000 . Because of the significance value $(0.000<0.05), \mathrm{Ha}$ is accepted, meaning that there is a significant positive relationship between the intensity of social media and academic procrastination.

The research results above show that the social media variable is a big distraction, and most of it comes from social media. Procrastination overall is something a lot of people deal with, and what happens with procrastination is the reason that follows. Procrastination is something that students face every day, and the presence of social media makes students more likely to do academic procrastinate. It appears to be a selfregulation failure, one of which causes problematic phone use. Several studies have shown that low levels of self-regulation predict greater Internet/mobile use, as well as negative consequences such as anxiety and procrastination (Yang et al., 2018).

In line with the results of research conducted by Andiryani that one of the factors that influence academic procrastination is the tendency to choose something based on pleasure. Social media is one of the means to bring joy to students. This study indicates that one of the main factors that influence academic procrastination is the use of mobile phones or the like to play social media (Andriyani, 2018). Field data also shows that other factors besides the intensity of social media affect students' academic procrastination, namely parenting patterns. As a parent, of course, you don't want to be seen as unable to take care of your child correctly, giving rise to various efforts to show others that they can take good care of their child (Latipah et al., 2020). But in reality, the lack of parental attention results in a lack of motivation and self-regulation in student learning, where students will often play social media and cause delays in doing their academic assignments.

Apart from parenting, many friends can be a source of negative behaviour. The more friends, the greater the chance for negative behaviour to be accepted by children; besides, experience, cognitive development, socio-emotional, and even religion affect students' negative behaviour (Latipah et al., 2021). Having a friend who likes to be lazy will be carried away by his laziness and vice versa. When a student has a diligent friend, he will be carried away diligently.

\section{F. Conclusion}

The study results conclude that, partially, there is a significant negative relationship between self-regulated learning and academic procrastination. It is called negatively related because based on the results, it can be interpreted that the higher the self- 
regulated learning that students have, the lower their academic procrastination will be. On the other hand, it was also found that there was a significant positive relationship between the intensity of social media and academic procrastination. This means that the rise will follow an increase in the power of social media in academic procrastination, and a decline will follow a decrease in the intensity of social media in academic procrastination. Based on the study results, it can also be seen that simultaneously or together, there is a significant positive relationship between self-regulated learning and the intensity of social media on academic procrastination, which is $30.5 \%$. In comparison, $69.5 \%$ is influenced by other variables outside of this study.

The study results recommend that it is necessary to emphasize self-regulation and good learning motivation to reduce student procrastination. Schools should design learning programs by current conditions, which are still carried out online so that students do not feel bored and are always enthusiastic about learning every day. It is hoped that further researchers will be able to develop research on self-regulated learning, the intensity of social media, and academic procrastination because there are still many shortcomings and obstacles in the research process. Further research can be further developed by using a more comprehensive and quality population, and if researching academic procrastination can use factors, data analysis that is different from this research.

\section{BIBLIOGRAPHY}

Aini, A. N., \& Mahardayani, I. H. (2017). Hubungan Antara Kontrol Diri Dengan Prokrastinasi Dalam Menyelesaikan Skripsi Pada Mahasiswa Universitas Muria Kudus. Jurnal Psikologi Pitutur, 1(2), 65-71.

Andriyani, A. (2018). Social Media User Students' Academic Procrastination. Psikopedagogia Jurnal Bimbingan Dan Konseling, 7(2), 53-57. Https://Doi.Org/10.12928/Psikopedagogia.V7i2.12934

Anggawijaya, S. (2013). Hubungan Antara Depresi Dan Prokrastinasi Akademik Sabatini Anggawijaya. Jurnal Ilmiah Mahasiswa Universitas Surabaya, 2(2), 1-12.

Bernacki, M. L., Nokes-Malach, T. J., \& Aleven, V. (2015). Examining Self-Efficacy During Learning: Variability And Relations To Behavior, Performance, And Learning. Metacognition And Learning, 10(1), 99-117. Https://Doi.Org/10.1007/S11409-014-9127$X$

Brandmayr, M. (2020). Self-Regulated Learning, Equality Of Opportunities And The Mediation Of Ideologies: A Discourse Study Of The Austrian School System. Journal For Critical Education Policy Studies, 18(1), 335-366.

Crone, E. A., \& Konijn, E. A. (2018). Media Use And Brain Development During Adolescence. Nature Communications, 9(1). Https://Doi.Org/10.1038/S41467-018$03126-X$

Damri, D., Engkizar, E., \& Anwar, F. (2017). Hubungan Self-Efficacy Dan Prokrastinasi Akademik Mahasiswa Dalam Menyelesaikan Tugas Perkuliahan. Jurnal Edukasi: Jurnal Bimbingan Konseling, 3(1), 74. Https://Doi.Org/10.22373/Je.V3i1.1415 
Eva Latipah et al.

Fauziah, H. H. (2016). Fakor-Faktor Yang Mempengaruhi Prokrastinasi Akademik Pada Mahasiswa Fakultas Psikologi Uin Sunan Gunung Djati Bandung. Psympathic : Jurnal Ilmiah Psikologi, 2(2), 123-132. Https://Doi.Org/10.15575/Psy.V2i2.453

Ferrari, J. R., \& Tice, D. M. (2000). Procrastination As A Self-Handicap For Men And Women: A Task-Avoidance Strategy In A Laboratory Setting. Journal Of Research In Personality, 34(1), 73-83. Https://Doi.Org/10.1006/Jrpe.1999.2261

Ika Sandra, K., \& Djalali, M. A. (2013). Manajemen Waktu, Efikasi-Diri Dan Prokrastinasi.
Persona:Jurnal
Psikologi
Indonesia,
2(3),
217-222.

Https://Doi.Org/10.30996/Persona.V2i3.140

Ilyas, Muhammad \& Suryadi. (2017). Perilaku Prokrastinasi Akademik Siswa di SMA Islam

Terpadu (IT) Boarding School Abu Bakar Yogyakarta. Jurnal An-nida Jurnal Pemikiran Islam, 41 (1).

Jannah, M., \& Muis, D. T. (2014). Prokrastinasi Akademik (Perilaku Penundaan Akademik) Mahasiswa Fakultas Ilmu Pendidikan Universitas Negeri Surabaya. Jurnal Bk Unesa, $4(3), 1-8$.

Kesuma, A. T., Harun, Zamroni, Putranta, H., \& Kistoro, H. C. A. (2020). Evaluation Of The Self-Regulated Learning Model In High Schools: A Systematic Literature Review. Universal Journal Of Educational Research, 8(10), 4792-4806. Https://Doi.Org/10.13189/Ujer.2020.081051

Kim, K. R., \& Seo, E. H. (2015). The Relationship Between Procrastination And Academic Performance: A Meta-Analysis. Personality And Individual Differences, 82, 26-33. Https://Doi.Org/10.1016/J.Paid.2015.02.038

Knaus, W. (2010). End Procrastination Now: Get It Done With A Proven Psichological Approach. Mcgraw-Hill.

Kroese, F. M., De Ridder, D. T. D., Evers, C., \& Adriaanse, M. A. (2014). Bedtime Procrastination: Introducing A New Area Of Procrastination. Frontiers In Psychology, 5(Jun). Https://Doi.Org/10.3389/Fpsyg.2014.00611

Kurniasanti, K. S., Assandi, P., Ismail, R. I., Nasrun, M. W. S., \& Wiguna, T. (2019). Internet Addiction: A New Addiction? Medical Journal Of Indonesia, 28(1), 82-91. Https://Doi.Org/10.13181/Mji.V28i1.2752

Latipah, E. (2010). Strategi Self Regulated Learning Dan Prestasi Belajar: Kajian Meta Analisis. Jurnal Psikologi, 37(1), 110-129-129. Https://Doi.Org/10.22146/Jpsi.7696

Latipah, E., Kistoro, H. C. A., \& Khairunnisa, I. (2020). Scientific Attitudes In Islamic Education Learning: Relationship And The Role Of Self-Efficacy And Social Support. Edukasia: Jurnal Penelitian Pendidikan Islam, 15(1), 37. Https://Doi.Org/10.21043/Edukasia.V15i1.7364

Latipah, E., Kistoro, H. C. A., \& Putranta, H. (2020). The Effects Of Positive Parenting Toward Intolerance In Pre-School Children. International Journal Of Early Childhood Special Education, 12(2), 137-146. Https://Doi.Org/10.9756/Int-Jecse/V12i2.201065

Latipah, E., Kistoro, H. C. A., \& Putranta, H. (2021). How Are The Parents Involvement, Peers And Agreeableness Personality Of Lecturers Related To Self-Regulated Learning? European Journal of Educational Research, 10(1), 413-425. 
Academic Procrastination of High School Students During the Covid-19 Pandemic

Https://Doi.Org/10.12973/Eu-Jer.10.1.413

Motie, H., Heidari, M., \& Sadeghi, M. A. (2012). Predicting Academic Procrastination During Self-Regulated Learning In Iranian First Grade High School Students. Procedia - Social And Behavioral Sciences, 69(Iceepsy 2012), 2299-2308. Https://Doi.Org/10.1016/J.Sbspro.2013.02.023

Munawaroh, M., Alhadi, S., \& Saputra, W. (2017). Tingkat Prokrastinasi Akademik Siswa Sekolah Menengah Pertama Muhammadiyah 9 Yogyakarta. Jurnal Kajian Bimbingan Dan Konseling, 2(1), 26-31. Https://Doi.Org/10.17977/Umoo1v2i12017po26

Ni'matuzahroh. (2019). Aplikasi Psikologi Di Sekolah:Teori Dan Praktik Dalam Memahami Masalah-Masalah Di Sekolah. Umm Press.

Nitami, M., Daharnis, D., \& Yusri, Y. (2015). Hubungan Motivasi Belajar Dengan Prokrastinasi Akademik Siswa. Konselor, 4(1), 1. Https://Doi.Org/10.24036/02015416449-0-00

Nugteren, M. L., Jarodzka, H., Kester, L., \& Van Merriënboer, J. J. G. (2018). SelfRegulation Of Secondary School Students: Self-Assessments Are Inaccurate And Insufficiently Used For Learning-Task Selection. Instructional Science, 46(3), 357-381. Https://Doi.Org/10.1007/S11251-018-9448-2

Park, S. W., \& Sperling, R. A. (2012). Academic Procrastinators And Their Self-Regulation. Psychology, 03(01), 12-23. Https://Doi.Org/10.4236/Psych.2012.31003

Radino, Kistoro, H. C. A., Munajat, N., Putranta, H., Kesuma, A. T., \& Lumaurridlo. (2021). Distance Learning Strategies Using Technology For Elementary School Students In Yogyakarta During The Covid-19 Pandemic. Journal Of Theoretical And Applied Information Technology, 99(9), 2031-2039.

Ramadhan, R. P., \& Winata, H. (2016). Prokrastinasi Akademik Menurunkan Prestasi Belajar Siswa. Jurnal Pendidikan Manajemen Perkantoran, 1(1), 154. Https://Doi.Org/10.17509/Jpm.V1i1.3260

Rea, L. M., \& Parker, Richard A. (2014). Designing And Conducting Survey Research: A Comprehensive Guide (Fourth Edi). Jossey-Bass.

Saman, A. (2017). Analisis Prokrastinasi Akademik Mahasiswa (Studi Pada Mahasiswa Jurusan Psikologi Pendidikan Dan Bimbingan Fakultas Ilmu Pendidikan). Jurnal Psikologi Pendidikan Dan Konseling: Jurnal Kajian Psikologi Pendidikan Dan Bimbingan Konseling, 3(2), 55. Https://Doi.Org/10.26858/Jpkk.Voio.3070

Ulum, M. I. (2016). Strategi Self-Regulated Learning Untuk Menurunkan Tingkat Prokrastinasi Akademik Siswa. Psympathic: Jurnal Ilmiah Psikologi, 3(2), 153-170. Https://Doi.Org/10.15575/Psy.V3i2.1107

Virtanen, P., Nevgi, A., \& Niemi, H. (2015). Self-Regulation In Higher Education: Students' Motivational, Regulational And Learning Strategies, And Their Relationships To Study Success. Studies For The Learning Society, 3(1-2), 20-34. Https://Doi.Org/10.2478/Sls2013-0004

Wolters, C. A., \& Benzon, M. B. (2013). Assessing And Predicting College Students Use Of Strategies For The Self-Regulation Of Motivation. Journal Of Experimental Education, 81(2), 199-221. Https://Doi.Org/10.1080/00220973.2012.699901

Dinamika Ilmu, Volume 21(2), 2021 
Eva Latipah et al.

Yang, Z., Asbury, K., \& Griffiths, M. D. (2018). An Exploration Of Problematic Smartphone Use Among Chinese University Students: Associations With Academic Anxiety, Academic Procrastination, Self-Regulation and Subjective Wellbeing. Int J Ment Health Addiction, 1-19.

Zimmerman, M. A. (2013). Resiliency Theory: A Strengths-Based Approach To Research And Practice For Adolescent Health. Health Education And Behavior, 40(4), 381-383. Https://Doi.Org/10.1177/1090198113493782 